\title{
THE DIMENSIONS OF AMERICAN CONSTITUTIONAL EQUALITY
}

\author{
J. Harvie Wilkinson III*
}

I

\section{INTRODUCTION}

Liberty and equality are salient characteristics of any legal order. Of the two, liberty emerged first in this country. Indeed, the stirring preamble to the Constitution of the United States testifies to the preeminent place that "the Blessings of Liberty" held in the esteem of the Framers. The Bill of Rights, whose bicentennial we now celebrate, is largely concerned with rights of liberty, not rights of equality. Its emphasis on liberty is not difficult to explain. The American Revolution was largely a war over liberty. The Bill of Rights represented the fruition of a conflict fought to secure both freedom of self-governance and freedom from the reach of the omnipresent state.

Like the American Revolution, the Civil War was fought, in part, for powerful ideals. If the ideals of liberty and self-governance inspired the revolution, then the concepts of union, and later the first glimmers of equality, animated war aims in the North. The idea of equality became bound up in the ideal of freedom. However, even the conjoining of liberty and equality was not enough to prevent the Emancipation Proclamation from being Lincoln's most unpopular act at the time.

The fourteenth amendment embodied both wartime goals: union and equality. By its terms, the amendment operated as an express prohibition upon the states, and its command was, in some inchoate sense, an equalizing one. Although the word "equal" had appeared in the Constitution before, this amendment marked the first time that equality had appeared in any meaningful, aspirational sense. Thus, with the fourteenth amendment, liberty and equality, the two cornerstones of our constitutional system, were in place, and securely so, because each reflected the formative conflicts of our national experience.

Ironically, both constitutional liberty and constitutional equality took a long time to flower after these formative amendments took effect. The liberties represented in the Bill of Rights were not dramatically expanded until Justice Black's seminal dissent in Adamson $v$. Califormia ${ }^{1}$ laid the groundwork for later incorporation of most Bill of Rights provisions to the states. The dramatic debate between the liberty represented by local self-

Copyright $\odot 1992$ by Law and Contemporary Problems

* Judge, United States Court of Appeals for the Fourth Circuit.

1. 332 US 46,68 (1947) (Black dissenting). 
governance and the liberty represented by a national application of our fundamental freedoms was joined only after World War II.

Similarly, the idea of constitutional equality took hold too belatedly. Exaggerated laissez-faire and a stultifying racism dominated the late nineteenth century and prevented constitutional equality from developing. Many of the Supreme Court's interventions in the first and fourth decades of this century were on behalf of privilege and property, ${ }^{2}$ despite the presence of Chief Justice Fuller and, later, Chief Justice Hughes, who were ambivalent about that course. As with the late-developing debate over incorporation, the idea of national constitutional equality began to emerge only in the aftermath of World War II. Its emergence was attributable to many causes, but none so much as the modern civil rights movement. Questions of racial dignity and equality began reaching the courts in the $1950 \mathrm{~s}$ and $1960 \mathrm{~s}$ in record numbers, not only because black plaintiffs challenged the existence of Jim Crow legislation, but also because authorities used trespass and disorderly conduct laws to quell civil rights demonstrations, which eventually brought black defendants to the Supreme Court. ${ }^{3}$

II

The Several Dimensions of Constitutional Equality

The ideal of racial justice lies at the core of modern constitutional equality. The dimensions of constitutional equality are, however, remarkably diverse. I shall try to explore several of these different dimensions of equality and address a few of the major cases associated with each. This exploration will ask what aspects of equality judges are permitted or obligated to promote. The answers in this controversial field are anything but simple. To say that Americans have enormously different views of equality, as well as of the role of the judiciary in achieving this equality, understates the problem. Although equality is a subject that is guaranteed to elude consensus, there should be some settled areas. For those areas that are unsettled, we should at least attempt to define the parameters of debate.

\section{A. Equality of Ideas and Beliefs}

All ideas and faiths must be equal in the eyes of the state. The first amendment, more than the equal protection clause, is the source of this first species of equality. Both the speech and religious clauses of the first amendment have, without question, a strong equality component. Although the state is free to promote its own programmatic agenda, it is not free to do so by suppressing ideas that it disagrees with or even those it finds heretical.

2. See, for example, Lochner v New York, 198 US 45 (1905) (invalidating state maximum work hours law); Morehead v New York, 298 US 587 (1936) (invalidating state minimum wage law).

3. See, for example, Adderley $v$ Florida, 385 US 39 (1966). 
All ideas are equal, and as such, the state must permit expression of the most and least agreeable among them. ${ }^{4}$

In the area of religious faith, the idea of equality is even more strictly enforced. The establishment clause makes it clear that the state is not permitted a positive religious agenda of any sort. Furthermore, under the free exercise clause, the state is not permitted to restrict observance of any religious faith. In contrast to the speech prong of the first amendment, the religion clauses impose an obstacle to the promotion, as well as to the discouragement, of any faith or tenet by the government. Equality of belief is promoted in the purest sense.

Despite the fundamental commitment to equality of ideas and beliefs in the first amendment, the notion of equality has still proven elusive or incomplete. For example, equality of ideas has never been thought to guarantee an equal amplification of the voices expressing ideas. An incumbent has a more potent forum than does a challenger; a TV anchorperson will be heard by millions more than a sidewalk orator; a wealthy citizen has a constitutionally protected right to spend large sums on his own campaign and may be able to purchase a forum for his message. ${ }^{5}$ Thus, to some extent, freedom has been dominant over equality in first amendment law.

Freedom has not, however, won a complete victory over equality. The tension between the two was evident in Austin $v$. Michigan Chamber of Commerce, ${ }^{6}$ where the Court upheld a Michigan law prohibiting the use of general corporate funds for independent expenditures to candidates in state elections. Justice Marshall's majority opinion struck a note of equality in deploring the unfair influence of corporate wealth in state elections. Justice Kennedy remonstrated against the majority's attempt to "equalize the relative influence of speakers."'7

In the religion cases, it is unclear which of two competing views is most consistent with the fundamental premise of equality. The exemptionist view, most prominently identified with Wisconsin $v$. Yoder, ${ }^{8}$ holds that the failure to except unconventional religious practices from the general operation of secular legislation in effect condemns those faiths to unequal treatment. The neutralist view, most prominently identified now with Oregon $v$. Smith, ${ }^{9}$ holds that finding constitutionally compelled exemptions for religious conduct from neutral "generally applicable" law is itself an example of unequal treatment. ${ }^{10}$ Thus, general agreement on the proposition that the religion clauses

4. United States $v$ Schwimmer, 279 US 644, $654-55$ (1929) (Holmes dissenting) (" [I]f there is any principle of the Constitution that more imperatively calls for attachment than any other it is the principle of free thought-not free thought for those who agree with us but freedom for the thought that we hate.").

5. Buckley v Valeo, 424 US 1,51-54 (1976).

6. 494 US 652 (1990).

7. Id at 704 .

8. 406 US 205 (1972).

9. 494 US 872 (1990).

10. Id at 885 . 
prescribe equality of religious belief breaks down when it becomes difficult to determine exactly what equal treatment of religious communities means.

\section{B. Equality of Participation}

Participatory equality sprang from a series of cases establishing the requirement of equal population for state legislative and congressional districts, popularly known as the "one person, one vote" rule. Baker $v$. Carr, 11 Reynolds $v$. Sims, ${ }^{12}$ and Wesberry $v$. Sanders ${ }^{13}$ are the seminal decisions in this area. If dilution of a person's vote was not to be countenanced, then certainly denial of the right to vote appeared even more repugnant. A spate of Supreme Court opinions in the 1960s and 1970s swept away various barriers to voting rights and ballot access. ${ }^{14}$ The salutary thrust of these decisions was to broaden and equalize political participation. One of these decisions, Harper v. Virginia Board of Elections, ${ }^{15}$ invalidated a poll tax that was neutral on its face but discriminatory in effect. The decision evoked what became perhaps the most famous outcry against contemporary constitutional equality:

It was not too long ago that Mr. Justice Holmes felt impelled to remind the Court that the Due Process Clause of the fourteenth amendment does not enact the laissez-faire theory of society ... . The times have changed, and perhaps it is appropriate to observe that neither does the Equal Protection Clause of that Amendment rigidly impose upon America an ideology of unrestrained egalitarianism. ${ }^{16}$

The idea of participatory equality, however, was not confined either to politics or to the equal protection clause. In a broader sense, participatory equality sought to ensure that indigent persons would be placed on a more equal footing with respect to the many governmental decisions that affected them. For example, Gideon $v$. Wainwright ${ }^{17}$ promoted a greater equality of participation within the criminal justice system by guaranteeing to indigents the appointment of counsel in felony cases. This guarantee was later extended to all instances where imprisonment would be imposed. ${ }^{18}$ Similarly, Goldberg $v$. Kelly ${ }^{19}$ promoted participatory equality with respect to bureaucratic decisions by mandating a hearing before certain welfare benefits were withdrawn.

All of these decisions afforded less affluent Americans a greater right of participation in the various processes of government, whether the vehicle was

\footnotetext{
11. 369 US 186 (1962) (reapportionment cases are justiciable under the equal protection clause).

12. 377 US 533 (1964) (state legislative seats must be apportioned substantially on a population basis).

13. 376 US 1 (1964) (congressional districts)

14. See, for example, Harper v Virginia Bd. of Elections, 383 US 663 (1966) (state poll tax); Kramer v Union Free School District No. 15, 395 US 621 (1969) (property requirement); Dunn v. Blumstein, 405 US 330 (1972) (durational residency requirement). See also William v. Rhodes, 393 US 23 (1968) (invalidating barriers to ballot access).

15. 383 US 663 (1966).

16. Id at 686 (Harlan dissenting) (citing Lochner, 198 US 45, 75-76).

17. 372 US 335 (1963).

18. Argersinger v Hamlin, 407 US 25 (1972).

19. 397 US 254 (1970).
} 
that of the sixth amendment or the due process clause. In Gideon, the Court combined the idea of equality with the importance of presuming the individual liberty of innocent persons. In Goldberg, the Court expanded the realm of property from strict notions of realty and personalty, encompassing a range of less tangible entitlements to public employment and assistance. ${ }^{20}$

Most of the decisions stopped short of requiring the achievement of complete equality. After all, the sixth amendment gives an indigent defendant the right to an appointed counsel, not to the public payment of the fees of any person retained by an indigent defendant. ${ }^{21}$ All of the cases granting participatory equality to indigents focus on procedural remedies. The cases do not guarantee that the outcome of an election, the verdict of a jury, the decision of a bureaucrat, or the action of a public employer will be favorable, or even correct. The cases carefully balance the desirability of greater procedural safeguards against the dangers of governmental immobility. ${ }^{22}$ These decisions, however, suggest that courts will allow the imposition of substantial public costs in order to ensure that public processes will be more fair.

\section{Equality under the Law}

The basic notion of equality under the law is a simple and appealing one: no one is above the law. The idea has been with us at least since Runnymede. The most celebrated modern embodiment of this concept is contained in United States $v$. Nixon, ${ }^{23}$ where the Court held that even the President of the United States was subject to legal process designed to obtain evidence for a pending criminal trial. The events of Watergate placed a renewed emphasis upon the notion that all persons were subject to the law. The Ethics in Government Act of $1978^{24}$ expressed the desire of Congress that high executive branch officials remain accountable. The Court upheld the act against separation of powers objections in Morrison $v$. Olson.$^{25}$ In Morrison, as in Nixon, contentions that the ethics act compromised the independence of the executive branch fell victim to the Court's and Congress's conclusion that executive privilege is not absolute and that no official is above the law.

The engrafting of legal accountability onto political accountability in the Nixon and Morrison decisions was a portentous step. It represented, in essence, a loss of faith in the curative potential of democracy and an increasing determination to use the law as an antidote to perceived abuses by the powerful and privileged. The United States Sentencing Commission

20. See Bell v Burson, 402 US 535 (1971) (driver's license); Perry v Sindermann, 408 US 593 (1972) (state employment); Goss v Lopez, 419 US 565 (1975) (school attendance).

21. See, for example, Caplin E Drysdale, Chartered v United States, 491 US 617, 624 (1989) ("[T]hose who do not have the means to hire their own lawyers have no cognizable complaint so long as they are adequately represented by attorneys appointed by the courts.").

22. See, for example, Mathews v Eldridge, 424 US 319 (1976).

23. 418 US 683 (1974).

24. Pub L No 95-521, 92 Stat 1824 , codified at 2 USCS $\S \S 288$ et seq (1991).

25. 487 US 654 (1988). 
recently promulgated guidelines that emphasized this theme of equality under the law. ${ }^{26}$

Much the same debate over equality under the law for persons in high places is occurring with respect to state officials charged in federal court with violating federal constitutional rights. The doctrine of sovereign immunity has traditionally protected the state from suit and appears to subordinate notions of equality under law to the ancient adage that "the king can do no wrong." As with senior executive officials, the historical antidote for potential abuse was thought to be political. The people, through their legislative voice, can abrogate the sovereign immunity concept anytime they choose.

However, the great battle in this area of equality is not being fought in legislatures, but rather in those cases defining immunity for defendants in actions under 42 USC section 1983 . Those who hold a strict view of equality under the law argue for a restrictive definition of immunity on the grounds that no executive official, no matter how powerful, should be free to violate the constitutional rights of the citizenry with impunity. Others believe that enforcing strict equality under the law through the withdrawal of executive immunity would make enforcement of the law impossible. The debate creates a stunning paradox. To preserve enforcement of the law, and ultimately the rule of law, some dispensation by way of immunity must plainly be granted to executive officials. The appeal, however, of the ideal of equality under law continues to manifest itself in the Supreme Court's reluctance to confer grants of immunity from the Civil Rights Act in an absolute, rather than a qualified, form. ${ }^{27}$

\section{Equality of Status}

Equality of status addresses the fundamental constitutional prohibition against discrimination on the basis of status or membership in a racial, ethnic, or gender-based group. Legislation that classifies on these suspect bases is subject to the strictest constitutional scrutiny. In a sense, footnote four of United States v. Carolene Products $\mathrm{Co}^{28}$ foreshadowed the concept of the suspect classification by calling for a "searching judicial inquiry" of statutes evidencing "prejudice against discrete and insular minorities."29

However, the political power of these minorities has grown substantially in the years since Carolene Products. Statutes designed to protect the rights not only of racial and ethnic minorities and women, but also of the aged, ${ }^{30}$ the

26. See Sentencing Reform Act of 1984, Pub L No 98-473, 98 Stat 1988, codified at 18 USC $\S 3551$ (1988). The Supreme Court upheld the guidelines against separation of powers objections, noting the power of Congress to provide for more uniform and determinate sentencing. Mistretta $v$ United States, 488 US 361 (1989).

27. See, for example, Forrester v White, 484 US 219 (1988) (no absolute immunity for judges exercising administrative rather than judicial powers).

28. 304 US 144 (1938).

29. Id at $152-53 \mathrm{n} 4$.

30. Age Discrimination in Employment Act of 1967, Pub L No 90-202, 81 Stat 602, codified as amended at 29 USC $\S \S 621-34$ (1988). 
handicapped, ${ }^{31}$ and the mentally ill and retarded ${ }^{32}$ demonstrate the increased political power of these groups. The action in the area of discrimination has switched, to a considerable extent, from the constitutional realm to hotly debated questions of statutory construction. Congress's reaction to the Supreme Court's interpretation of civil rights laws in Grove City College v. Bell, ${ }^{33}$ Wards Cove Packing Co. v. Atonio, ${ }^{34}$ and Patterson v. McLean Credit Union ${ }^{35}$ demonstrates that the critical cases now focus on the scope and coverage of federal anti-discrimination legislation rather than the invalidation of discriminatory state laws. The shift is a measure of the progress made in rooting out the more overt manifestations of inequality of status. With this shift, conflict has diminished somewhat between the federal judiciary and the states, but the potential for conflict between the Court and Congress may be growing.

One wonders how constitutional doctrine will adapt to this political change. The concept of the suspect classification was never an entirely tidy tool of constitutional jurisprudence. Under this concept, some classes are suspect, while other classes are only semi-suspect. The lines between minimal, intermediate, and strict scrutiny of various classifications have always been blurred. ${ }^{36}$ Although the earliest suspect classification cases almost always involved de jure discrimination against classes, debate has raged over how de facto classifications should be scrutinized. Finally, the Carolene Products rationale for suspect classifications-protecting discrete and insular minorities-has been sorely tested by white or male plaintiffs contesting affirmative action plans. ${ }^{37}$ Such lawsuits underscore a certain confusion in the concept of suspect classifications and in the reasons why suspect status is conferred upon certain groups. Was it the group's minority status, powerless position, or the invidious nature of legal distinctions resting upon immutable characteristics that caused suspect status to be conferred upon it?

The danger exists here that one may miss the forest by looking only at the trees. The vehicle of the suspect classification has taught Americans more about the intrinsic nature of discrimination than any other constitutional device. Attitudinal stereotypes are at the heart of discriminatory laws. In invalidating overbroad classifications under the equal protection clause, the courts struck equally at the underlying fallacies of racial, sexual, and ethnic stereotypes. Additionally, releasing individuals from legal subjugation on the basis of some supposed group characteristic promotes both paramount constitutional values. The soundest constitutional decisions may be those that

31. Rehabilitation Act of 1973, Pub L No 93-112, 87 Stat 355, codified at 29 USC $\S \S 701$ et seq (1988).

32. Civil Rights of Institutionalized Persons Act, Pub L No 96-247, 94 Stat 349, codified as amended at 42 USC $\S \S 1997-1997 \mathrm{j}(1988)$.

33. 465 US 555 (1984).

34. 490 US 642 (1989).

35. 491 US 164 (1989).

36. See Gerald Gunther, In Search of Evolving Doctrine on a Changing Court, 86 Harv L. Rev 1 (1972).

37. See, for example, Regents of the Liniv. of Cal. $v$ Bakke, 438 US 265 (1978). 
do not involve agonizing tradeoffs between liberty and equality. In advancing the fourteenth amendment ideal of equal and individualized treatment of all citizens regardless of race, ethnicity, or gender, the courts have advanced the great constitutional ideal of liberty as well.

\section{E. Equality of Opportunity}

Equality of opportunity in America is certainly not a matter that any branch of government can simply ignore. However, equality of opportunity is the most open-ended dimension of equality that I have discussed. It presents a staggering definitional difficulty, especially for the courts. For example, is equality of opportunity promoted or undermined by affirmative action plans or by public assistance programs? The answers to such questions are highly value-laden, and the costs to the judiciary in entering the argument are always steep. As a philosophical matter, one might argue that equality of opportunity cannot be secured until inequalities of means are eliminated. As a practical matter, however, such an enterprise lies beyond the reach of the most committed court. The danger of an untempered endorsement of equality of opportunity as a goal of the equal protection clause should be apparent.

The Supreme Court has had to pick carefully the areas in which to promote the goal of equality of opportunity. At first blush, the most likely area may appear to be education, both because it was the setting of the Brown decision and because it represents the most direct means of upward mobility and self-betterment. Educational opportunity is, in the public mind, free of the stigmatic debate over "handouts" that may accompany the more direct forms of public welfare assistance. However, two major Texas school cases of the past two decades serve to underscore the difficulties of a judicial venture on behalf of equality of educational opportunity. In San Antonio Independent School District $v$. Rodriguez, ${ }^{38}$ the formidable complexity of school finance and educational policies forced the Court's restraint with respect to financial disparities among school districts. The school system's operations comprised a veritable educational thicket that dwarfed even the "political thicket" 39 that had long counseled judicial restraint under the political question doctrine. However, this theme of surpassing and intractable complexity apparently did not deter the majority in the other great Texas school case, Plyler v. Doe. ${ }^{40}$ In Plyler, the Court held Texas's denial of free public education to illegal aliens a violation of the equal protection clause. The various opinions supporting the result are as replete with warm thoughts as with workable doctrine. The doctrinal difficulty is that burdens upon educational rights must be supported by legitimate public interests, and in the course of disapproving those various interests in Plyler, the Court came close to installing its own educational preferences.

38. 411 US 1 (1973).

39. Colegrove v Green, 328 US 549, 556 (1946) (Frankfurter).

40. 457 US 202 (1982). 
Certainly, the compassionate, and probably the wisest, view holds that more money spent on the children of illegal immigrants today will cut the "costs of unemployment, welfare, and crime" 41 tomorrow. However, that argument would literally support a limitless range of judicially mandated educational expenditures. In fact, the Court seemed to recognize that its rationale should be reserved for the most egregious cases, those involving outright denials of education rather than relative deprivations. ${ }^{42}$ The problems in American education today are vast and varied, but it seems clear that in resolving them, we shall have to place much of our faith in state courts $^{43}$ and in democracy.

\section{F. Economic Equality}

The flashing amber lights that cause courts to show restraint with regard to equality of opportunity begin to turn red in the area of economic equality. Dandridge $v$. Williams ${ }^{44}$ sent the signal that the Court would approach questions of economic equality with caution. Although not a landmark case in popular circles, Dandridge has become a critical underpinning of modern judicial restraint. The Court upheld an upper limit placed by the state of Maryland on the total amount of Aid to Families with Dependent Children ("AFDC") benefits that any single family could receive, even though that family's standard of need as computed by the state would not be met by the grant. Justice Marshall was quite candid in dissent:

It is the individual interests here at stake that, as the Court concedes, most clearly distinguish this case from the "business regulation" equal protection cases. AFDC support to needy dependent children provides the stuff that sustains those children's lives: food, clothing, shelter. ${ }^{45}$

Dandridge demonstrates that the social importance of a burdened right "is not the critical determinant for subjecting state legislation to strict scrutiny." 46 In fact, it is difficult to think the matter could be otherwise. If a correlation was made between social importance and constitutional solicitude, a society committed to democratic governance would soon find the lion's share of its business transferred to the courts. Of course, the existence of a fundamental constitutional right to welfare might not dictate to Congress how to fund it any more than a right to counsel has precluded different methods of funding legal representation. However, the judiciary would face the temptation to police programs of public assistance for their adequacy or to judge the relative fairness of distributions to different classes of beneficiaries.

The wrangling over budgets and deficits that takes place each year in Congress and in state legislatures is the ultimate grist for the political mill.

41. Id at 230 .

42. Id at 234-35 (Blackmun concurring); id at $239 \mathrm{n} 3$ (Powell concurring).

43. See, for example, Edgewiood Indep. School Dist. v Kirby, 777 SW2d 39I (Tex 1989) (holding school financing system violated the Texas Constitution).

44. 397 US 471 (1970).

45. Id at 522 (Marshall dissenting).

46. Rodriquez, 411 US at 32. 
Elected officials should be allowed to struggle over questions of taxation and expenditure without an overlay of fundamental economic rights imposed by the Supreme Court. Such a set of rights would consist of little more than a thinly veiled judicial fiscal policy with a tilt toward social welfare spending and would offend Article I's allocation of powers to the legislative branch. The amelioration of poverty is one of those desirable ends which have generated endless controversy as to means, and the intersection of a democratic polity with market forces is what political discourse is about. Of course, laws that single out the poor for punitive treatment or that burden an individual's participatory rights should not escape judicial scrutiny, but in the end, policies of distribution are what the more important congressional committees have been created to debate.

\section{G. Numerical Equality}

The final dimension of equality involves the achievement of numerical proportionality among racial and ethnic groups, particularly in the schools and in the workplace. This profoundly controversial category of equality links decisions in such areas as school busing and affirmative action. The reasoning on numerical equality can generally be divided into two approaches: forwardlooking or aspirational, and backward-looking or reparational. Several of the opinions in $B a k k e^{47}$ furnish well-known examples of the reparational approach. Both Justice Brennan and Justice Marshall in their separate opinions discussed this country's tragic history of slavery and Jim Crow laws. The university justified its admissions policy partly on the basis of a desire to remedy past discrimination. In contrast, Chief Justice Warren's opinion in Brown represents an aspirational approach. ${ }^{48}$ He made limited mention of history and instead defined a goal of non-discrimination in public schools without extended reference to the wrongs that had been done to blacks earlier.

Both the aspirational and reparational approaches have their function, but the struggle is over how to combine these approaches to achieve a true measure of equality. For some, the United States' history of racial discrimination requires a lengthy period of continuing rectification, making measures such as the race-conscious allocation of jobs and college admissions constitutionally permissible. Others feel that every racial distinction in law only prolongs racial perceptions in society. For them, the goal of a colorblind Constitution is so compelling, and the continuation of governmentsponsored discrimination so pernicious, that the end of all racial classifications must begin now.

The debate centers on a disagreement over the proper use of history as a basis of and a limit to judicial intervention. ${ }^{49}$ Every civil rights case requires

47. 438 US 265 (1978).

48. Brown v Bd. Educ. of Topeka, 347 US 483 (1954).

49. Both sides of the affirmative action debate appear to recognize the important role that this disagreement plays. See the stimulating discussion of the temporal element in the Court's earlier 
some historical inquiry because without a past violation of a right, a court cannot provide a remedy. It is not clear, however, how broadly into the past the inquiry must reach. The more narrowly defined the past discrimination and injury, the more guidance these past wrongs give courts in determining appropriate remedies. As Justice Powell noted in Bakke, there is a difference between remedying "wrongs worked by specific instances of racial discrimination," and remedying "the effects of 'societal discrimination,' an amorphous concept of injury that may be ageless in its reach into the past."50

The reparational approach in civil rights law has developed primarily in the two areas that have promised the greatest upward mobility-education and employment. Predictably, however, the reparational view of law has also met its toughest opposition in the same two areas. The ideals of individual opportunity and individual merit-two critical elements of the aspirational vision-have combined to resist class-based reparations and remedies. The dilemma has been profound. In education, the reparational approach is expressed in the constitutional obligation of most school districts to "dismantle dual school systems" 51 that have been intentionally segregated by school authorities in violation of the constitutional guarantee of equal protection. In 1968, the Supreme Court in Green v. County School Board of New Kent County, Virginia ${ }^{52}$ charged dual school systems with the affirmative duty to eliminate the vestiges of racial discrimination root and branch by taking all necessary steps to convert to a unitary system. In 1971, the Court in Swann v. Charlotte-Mecklenburg Board of Education ${ }^{53}$ made it clear that the constitutional obligation to dismantle dual school systems might entail the compulsory transportation of students. The Supreme Court has limited transportation remedies in school desegregation cases, however, to reflect the actual record of prior segregation. ${ }^{54}$ In Milliken $v$. Bradley, for example, the Court observed that "[d]isparate treatment ... occurred within the Detroit school system, and not elsewhere, and on this record the remedy must be limited to that system." 55

Although the duty to dismantle dual systems has been the reparational focus of educational numerical equality, there has also been an aspirational focus. At some point, courts must confine the historical inquiry and begin moving the constitutional focus from the past to the future. A natural period of contrition and atonement must eventually give way to a fresh inquiry into the present imperatives of justice. In constitutional law, this idea of a fresh start is embodied in a concept known as "unitariness." When a school district

affirmative action decisions in Kathleen Sullivan, Sins of Discrimination: Last Term's Affrmative Action Cases, 100 Harv L Rev 78 (1986).

50. Bakke, 438 US at 307 (Powell).

51. Swann v Charlotte-Mecklenburg Bd. of Educ., 402 US 1, 22 (1971).

52. 391 US $430,437-38$ (1968).

53. 402 US 1 (1971).

54. Dayton Bd. of Educ. v Brinkman, 433 US 406 (1977); Pasadena City Bd. of Educ. v Spangler, 427

US 424 (1976); Milliken I' Bradley, 418 US 717 (1974).

55. $418 \mathrm{US}$ at 746 . 
achieves a unitary system, the constitutional obligation of that school district to make amends for historic segregation through race-conscious remedies ends.

In Board of Education of Oklahoma City Public Schools v. Dowell, 56 the Supreme Court recently revisited the issue of when a school district's obligations to correct past discrimination have been satisfied. The Court held that injunctions in school desegregation cases could be dissolved if the affected school board "had complied in good faith with the desegregation decree since it was entered, and . . . the vestiges of past discrimination had been eliminated to the extent practicable." 57 The Court emphasized that consideration of the latter factor requires an examination of " "every facet of school operationsfaculty, staff, transportation, extracurricular activities and facilities.' "58 Even after an injunction imposing a desegregation plan has been terminated, the school board's policies are still subject to challenge under the equal protection clause. ${ }^{59}$

The decision in Dowell nevertheless leaves many questions unanswered. It is not clear whether or to what extent the Court will permit voluntary affirmative action plans in a unitary system. More importantly, it is not clear exactly what school districts and school boards must to do maintain a unitary system and avoid repeating the sad and traumatic experience from which they have only recently emerged. For those school districts under federal court control, unitariness has been an ill-defined hope that they may one day return to a measure of self-governance, and that quality education may become the determinant of decisions on hiring, curriculum, construction, and assignment. For education, after all, is what schools are about.

The Supreme Court's views on affirmative action programs are even more complex. In recent years, the Court has seemed to reject the full reparationist view, which argues that the general societal history of slavery and segregation support present affirmative action efforts, in favor of subjecting raceconscious employment programs to a higher level of scrutiny. Such programs " 'must be justified by a compelling governmental interest' "60 and "the means chosen by the State to effectuate its purpose must be "narrowly tailored to the achievement of that goal." 61 Where a specific institution has discriminated against minorities previously, the Court has upheld courtordered affirmative action programs for that institution. ${ }^{62}$ For example, in

56. $111 \mathrm{~S} \mathrm{Ct} 630$ (1991).

57. Id at 638 .

58. Id, quoting Green v New Kent County School Bd., 391 US at 435.

59. Id. The Court cited Washington v Davis, 426 US 299 (1976), and Arlington Heights v Metropolitan Housing Development Corp., 429 US 252 (1977), as establishing the appropriate equal protection principles for such challenges.

60. Wygant v Jackson Bd. of Educ, , 476 US 267, 274 (1986), quoting Palmore v Sidoti, 466 US 429, 432 (1984).

61. Id at 274, quoting Fullilove $v$ Klutznick, 448 US 448, 480 (1980).

62. See, for example, Local 28 of the Sheet Metal Workers' Int'l Ass'n v Equal Employment Opportunity Comm ' $n, 478$ US 421 (1986). 
United States $v$. Paradise, ${ }^{63}$ the Court upheld a one-for-one promotions quota in a police department that had a history of persistent discrimination against blacks. On the other hand, the Court has also cautioned that a justification for racial quotas consisting of "a generalized assertion that there has been past discrimination in an entire industry . . . 'has no logical stopping point." "64 After making this observation, the Court went on to strike down Richmond's set-aside system that reserved 30 percent of the city's construction contracts for minority businesses because there was no evidence of illegal discrimination in the city's construction industry. ${ }^{65}$ Richmond's desire to remedy past discrimination in construction in general could not constitutionally justify such a rigid racial preference.

Such cases indicate that the Court has been moving closer to the aspirational view that race-conscious programs may serve narrow remedial purposes but not broad reparational ends. However, the Court's application of strict scrutiny to the race-conscious actions of cities and states is in contrast to the apparently more lenient equal protection scrutiny given congressionally mandated affirmative action programs. In Metro Broadcasting, Inc. v. F.C.C. ${ }^{66}$ the Court revisited its opinion in Fullilove v. Klutznick ${ }^{67}$ and reaffirmed that judicial deference is appropriate when Congress imposes benign race-conscious measures that substantially relate to important governmental objectives. Significantly, Congress's stated objective in granting certain preferences to minority and female broadcasting license applicants was to increase broadcast diversity, not to compensate victims of past governmental or societal discrimination. The dissent protested that the Federal Communication Commission's interest in increasing diversity was too amorphous to justify racial classifications, and that the granting of these preferences went beyond Congress's power under the fourteenth amendment to remedy past discrimination in the states. ${ }^{68}$

Although increasing diversity in broadcasting may appear a legitimate aspirational end, ${ }^{69}$ relying on this rationale to justify set-asides may also promote reparational goals. In a country as heterogeneous as the United States, it is clear that diversity is a desirable goal that needs encouragement. However, the benefits of diversity can invariably be invoked on behalf of every set-aside. In fact, the more rigid the set-aside, the greater the diversity it can arguably achieve. Thus, although diversity as a general matter is a desirable goal, diversity as a justification for every numerical set-aside becomes another reparational device. The law of affirmative action can neither be broadly reparational, nor can it ignore historical wrongs. Rather than discussing the

63. 480 US 149 (1987).

64. Richmond v J.A. Croson Co., 488 US 469, 498 (1989), quoting Wygant, 476 US at 275.

65. Id at 500-06.

66. 110 S Ct 2997 (1990).

67. 448 US 448 (1980).

68. Metro Broadcasting, $110 \mathrm{~S} \mathrm{Ct}$ at 3034 (O'Connor dissenting).

69. For the view that such diversity provides a legitimate aspirational basis for affirmative action, see Sullivan, 100 Harv L Rev 78 (cited in note 49). 
proper role of history in justifying race-conscious programs, Metro Broadcasting risks uncoupling such programs from remedial purposes entirely. Such a complete uncoupling through the device of diversity would give proponents of reparational policies as much a blank check for racial classifications as was provided by the earlier carte blanche of rectifying societal discrimination.

The ultimate question is whether equality means equality for individuals or equality for groups. If our society is to be governed under a rule of law, then our legal system must eventually rise above race. Our laws must have regularity and generality, and they must apply equally to all individuals. We are, first and foremost, human beings, not blacks or whites. As such, citizens deserve to stand before the law as individuals, not merely as representatives of a race. More common attributes unite us as members of the human race than can ever divide us by classification into other categories. This is not an exhortation to forget, for Americans must confront the ugly aspects of our history, including the eras of slavery and Jim Crow laws. There are differences, however, between learning from history and making it a basis for endless rounds of new decisions based on race. An aspirational approach to civil rights cases helps to ensure that the mistakes of the past will not be repeated, and that respect for the dignity of the individual human being transcends and overshadows all else.

III

The Judicial Role in Promoting Constitutional Equality

This brief survey of the dimensions of constitutional equality should make it apparent that the justification for judicial intervention on behalf of equality depends largely upon the kind of equality being promoted. In analyzing the equal protection clause, it is important to recognize that the concept of equality is capable of categorization and that such categorization is necessary to develop rationales both for intervention and restraint. ${ }^{70}$ The categorization and refinement of the question of equality are a remarkable phenomenon in constitutional law. For most of our nation's history, the idea of any judicial role on behalf of equal treatment would have been controversial.

The increased judicial role in promoting equality is mainly a modern phenomenon. Most of the major cases date from the Warren and Burger Courts. The modern nature of judicial intervention may impart a sense of inevitability to the notion that the judicial branch will continue to promote greater equality among citizens. The corollary of this notion is that the judiciary will acquiesce in legislative efforts designed to reduce disparities among citizens. Many contemporary students of constitutional law believe that whether the means be intervention or restraint, the judiciary will achieve greater equality as an end result.

70. See J. Harvie Wilkinson III, The Supreme Court, the Equal Protection Clause, and the Three Faces of Constitutional Equality, 61 Va L Rev 945 (1975). 
This perception overlooks much about the Court's history. For instance, a student of constitutional law in 1937 might have been just as certain that the natural role of courts was to serve as bastions of protection for the privileged. The Court seemed to have the necessary constitutional tools to accomplish that task: the contracts clause, ${ }^{71}$ the takings clause, ${ }^{72}$ the tenth amendment, the implied distinction between regulable commerce and unregulable production, ${ }^{73}$ and, above all else, substantive due process. ${ }^{74}$ Two of the more formidable judicial intellects of the late nineteenth and early twentieth centuries, Justice David Brewer and Justice George Sutherland, led the Court to strike down in the name of laissez-faire concededly rational legislative enactments designed to improve the conditions of American workers. In fact, the federal judiciary represented a major obstacle to the achievement of many fundamental reforms of the workplace, such as the minimum wage. ${ }^{75}$ Until the arrival of the first Roosevelt appointees to the Court, few regulations of business practices could avoid attack in federal court as violations of the due process clause, because the Court had broadly read the component of liberty to include not only freedom from physical restraint, but freedom of contract as well. ${ }^{76}$

Although the commerce clause decisions of the Roosevelt Court ${ }^{77}$ put decisively to rest many issues of judicial intervention on behalf of economic liberty, the debate over the desirability of intervention has continued among conservative constitutional scholars. For example, Professor Richard Epstein's restrictive view of the commerce power ${ }^{78}$ would invalidate a host of federal labor laws, and his expansive reading of the takings clause ${ }^{79}$ would nullify equally fundamental redistributionist legislation, such as the progressive income tax and other New Deal social legislation. His attempt to constitutionalize the unfettered market drew a sharp retort from none other than Judge Robert Bork. ${ }^{80}$ Although this skirmish between the two scholars is not likely to disturb the settled doctrine of the courts, it is useful as a historical reminder of the judicial influence constitutional laissez-faire doctrine had during the pre-Roosevelt era. The debate also highlights the subjective nature of arguments that an emphatic vision of constitutional equality or of constitutional inequality born of market conditions requires the invalidation of legislative acts.

71. US Const Art I, § 10, d 1 .

72. Id at Amend $\mathrm{V}$.

73. Id at Art I, § 8, cl 3.

74. See, for example, Lochner $v$ New York, 198 US 45 (1905).

75. See Adkins $v$ Children's Hosp., 261 US 525 (1923).

76. See Lochner, 198 US at 53.

77. See, for example, NLRB v Jones E Laughlin Steel Corp., 301 US 1 (1937); United States $v$ Wrightwood Dairy Co., 315 US 110 (1942); and Wickard v Filburn, 317 US 111 (1942).

78. See Richard Epstein, The Proper Scope of the Commerce Power, 73 Va L Rev 1387 (1987).

79. See Richard Epstein, Takings: Private Property and the Power of Eminent Domain (Harvard U Press, 1985).

80. Robert Bork, The Tempting of America 230 (Free Press, 1990). 
The nature of our political system presupposes not an overarching vision of equality, but rather a subtle interplay between market conditions and those corrective measures democratic institutions enact. The basic ingredients of this interplay are common knowledge. Simply put, the classic market rewards both skills and risks. Any market failing to reward these two qualities stifles the incentives necessary to maximize the larger sense of public well-being that the myriad instances of individual initiative are supposed to produce. A healthy market, for example, will presumably provide fertile conditions for raising venture capital and suitable rewards for the development of sophisticated skills indispensable to an increasingly demanding workplace. Of course, such a market will produce its share of business failures, and it may shut out a significant number of workers who fail to develop the skills necessary for changing conditions. Since many of these same citizens will also lack the inherited advantages made possible by the private transmission of wealth, their circumstances may be poignant.

Nothing in the Constitution makes the market sacrosanct. The Constitution does not forbid an array of public policies designed to maximize training and educational opportunities for those who have insufficient means of acquiring them. The Constitution does not prohibit an array of redistributionist policies in the form of progressive income and estate taxes and social welfare programs. Whether such initiatives are wise or not is the ultimate political question. It is difficult to argue, however, that the Constitution elliptically prevents Congress from softening the hardships produced by a strictly competitive system. To say that the Constitution removes such choices from popular government imparts inflexibility to our entire social system and exacerbates the edges of class divisions. Of course, a real danger exists that political intervention may destroy, for a time, the health and vitality of the market. However, the political constraints on market activity can be loosened and relaxed if conditions become too discouraging and too devoid of incentive for too many Americans.

It is tempting, therefore, to say that constitutional equality is primarily a question of separation of powers, and that, in general, equality should mean what the people, through their democratic institutions, say it means. Unfortunately, the problem is not that simple, because the judiciary is not given the luxury of simply standing on the sidelines. The last several decades of constitutional law have not made the judiciary a partner in the prescriptions for our economic health, but they have brought about a constitutional theory of equality which is approaching the more traditional theory of constitutional liberty. The traditional theory of liberty held that certain inalienable freedoms of the people were not subject to strict majority rule. Similarly, certain inalienable rights of equality now exist apart from the sufferance of the majority. The rights of equality, like the blessings of liberty, are not primarily economic in character. Instead, the new constitutional rights of equality are primarily dignitary rights. These include rights to equal expression, to nondiscriminatory treatment, to some threshold access to the political system, to 
basic levels of fair procedural treatment by public bureaucracies, and to equal application of the laws irrespective of affluence or position. These rights, like the rights of liberty, will always be the subject of fierce contention, and they will probably never be recognized in the expansive form that some Americans would prefer. Yet, because of the convergence of the constitutional theories supporting liberty and equality, the cause of human dignity has advanced. 


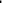

